\title{
Surface Roughness of Glass Ionomer Cements Indicated for Atraumatic Restorative Treatment (ART)
}

\author{
Renata Cristiane da SILVA \\ Angela Cristina Cilense ZUANON \\ Department of Pediatric Dentistry and Orthodontics, Faculty of Dentistry of Araraquara, \\ São Paulo State University, Araraquara, SP, Brazil
}

\begin{abstract}
The purpose of this study was to evaluate the surface roughness of four conventional chemically cured glass ionomer cements (Fuji IX, Ketac Molar, Vidrion R and Vitromolar) commonly used in atraumatic restorative treatment (ART) immediately after material preparation. Twenty specimens of each glass ionomer cement were fabricated and surface roughness was measured after material setting. The specimens were further examined under scanning electron microscopy. Data were analyzed statistically by Kruskal-Wallis test and Mann-Whitney test at 5\% significance level. Two-by-two comparisons showed statistically significant difference $(\mathrm{p}<0.05)$ between all materials, except for Ketac Molar and Vidrion R, which had statically similar results ( $p>0.05$ ). Regarding their results of surface roughness, the materials can be presented in a crescent order, as follows: Ketac Molar $<$ Vidrion $\mathrm{R}<$ Fuji IX $<$ Vitromolar. In conclusion, from the tested glass ionomer cements, Fuji IX, Ketac Molar and Vidrion R presented acceptable surface roughness after setting reaction while Vitromolar showed remarkably higher surface roughness.
\end{abstract}

Key Words: glass ionomer cement, atraumatic restorative treatment, surface roughness.

\section{INTRODUCTION}

Since their introduction by Wilson and Kent in the early 1970's, changes have been made in the original formulation of glass ionomer cements (GICs) to improve their clinical behavior $(1,2)$.

Among other indications, GICs have been used in the atraumatic restorative treatment (ART) to preserve dental structure and provide preventive and curative care to needy populations $(3,4)$. ART follows the concept of minimal intervention and involves hand excavation of carious tissue and use of conventional glass-ionomer cement as a filling material and a sealant to adjacent enamel fissures $(5,6)$. The use of highviscosity conventional GICs has been recommended for ART due to their improved mechanical properties, which are related to the size and type of filler particle content $(7,8)$.

Wear resistance and surface roughness in oral environment are important criteria to determine and predict the clinical deterioration of restorative materials (9-11). Surface characteristics of glass ionomer restorations are particularly important because rough surfaces might be prone to faster bacterial colonization and maturation of plaque, thus increasing caries risk (12).

The purpose of this study was to assess surface roughness of four glass ionomer cements commonly used for ART procedures.

\section{MATERIAL AND METHODS}

Four conventional chemically-cured glass ionomer cements were evaluated: Fuji IX (GC Corporation, Tokio, Japan), Ketac Molar (ESPE Dental AG, Seefeld, Germany), Vidrion R (SS White Artigos Dentários Ltda, Rio de Janeiro, RJ, Brazil) and Vitromolar (DFL Indústria e Comércio Ltda, Rio de Janeiro, RJ, Brazil). Except for Vidrion R, all other glass ionomer

Correspondence: Profa. Dra. Angela C. C. Zuanon, Departamento de Clínica Infantil, Faculdade de Odontologia de Araraquara, UNESP, Rua Humaitá, 1680, 14801-930 Araraquara, SP, Brasil. Tel: +55-16-201-6335. Fax: +55-16-201-6325. e-mail: aczuanon@foar.unesp.br 
cements were high-viscosity materials.

Twenty specimens of each material were fabricated according to manufacturers' instructions at controlled temperature of $23 \pm 2^{\circ} \mathrm{C}$. The amount of powder necessary to prepare each specimen was weighed in an electronic analytical balance (AS 310; Scientech Inc., Boulder, CO, USA) and mixed to the liquid with a spatula onto a impermeable mixing pad. Using a Centrix injector (Dentsply Ind. e Com. Ltda, Petrópolis, RJ, Brazil), the materials were inserted into polytetrafluoroethylene molds (4-mm thick; $7 \mathrm{~mm}$ in diameter) in a single increment and slowly to avoid bubble formation. The filled mould cavity was covered with a polyester strip and a glass slab, which was pressed down to extrude excess material. After $1 \mathrm{~h}$, the specimens were stored at 100\% relative humidity and were retrieved from the moulds after $24 \mathrm{~h}$.

The specimens were weighed in the electronic analytical balance (AS 310; Scientech Inc.) every $24 \mathrm{~h}$ until they presented a stable weight on 5 sequential measurements. The specimens did not undergo any kind of stress that could alter their surface morphology.

Surface roughness was analyzed in a roughness tester (Surfcorder SE 1700; Kosaka Laboratory Ltd, Kosaka, Japan) and was characterized by the height parameter, $R a(\mu \mathrm{m})$, defined as the arithmetical average of the absolute values of $3.1 \mathrm{~mm}$ surface profile. Three measurements passing through the centre of the specimen were performed and the average was obtained. The cut-off value was set at $0.25 \mathrm{~mm}$.

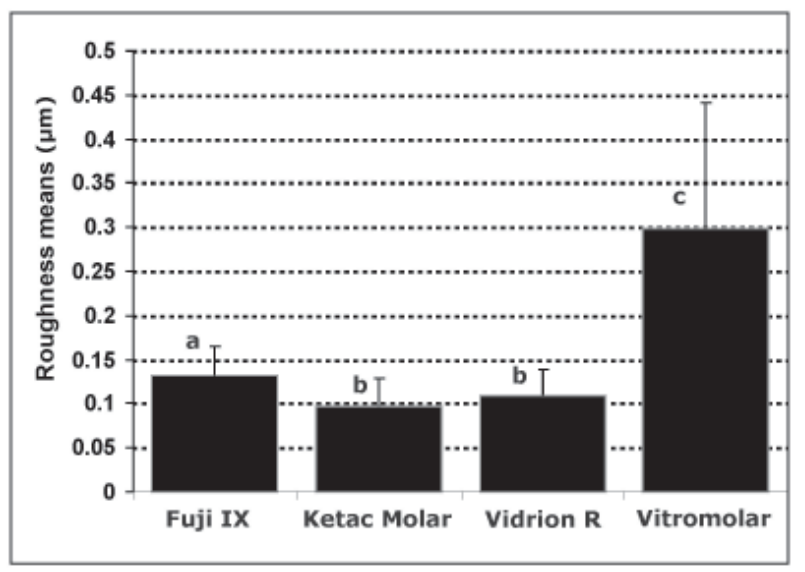

Figure 1. Surface roughness means ( $\mu \mathrm{m}$ ) of the tested conventional glass ionomer cements. Different letters indicate statistically significant difference at $\mathrm{p}<0.05$.
The specimens were further processed, sputtercoated with gold and examined using a scanning electron microscope (SM-300; Topcon, Tokyo, Japan). Photomicrographs were taken at X500 and X3000 magnifications.

Data were analyzed statistically by Kruskal-Wallis test and Mann-Whitney test for two-by-two comparisons. Significance level was set at $5 \%$.

\section{RESULTS}

Two-by-two comparisons by Mann-Whitney test revealed statistically significant difference $(p<0.05)$ between all materials, except for Ketac Molar and Vidrion $\mathrm{R}$, which had statically similar surface roughness means to each other ( $p>0.05$ ).

Ketac molar and Vidrion $\mathrm{R}$ glass ionomer cements presented the lowest surface roughness means, followed by Fuji IX and Vitromolar (Fig. 1).

SEM photomicrographs revealed that, in general, GIC surface presented voids and cracks (Fig. 2).

\section{DISCUSSION}

Glass ionomer cements have a great demand in pediatric dentistry due to their optimal characteristics, such as ability to chemically bond to enamel and dentin, biocompatibility, fluoride release, less volumetric contraction and coefficient of thermal expansion similar to that of tooth structure. Neverthless, their sensitivity to

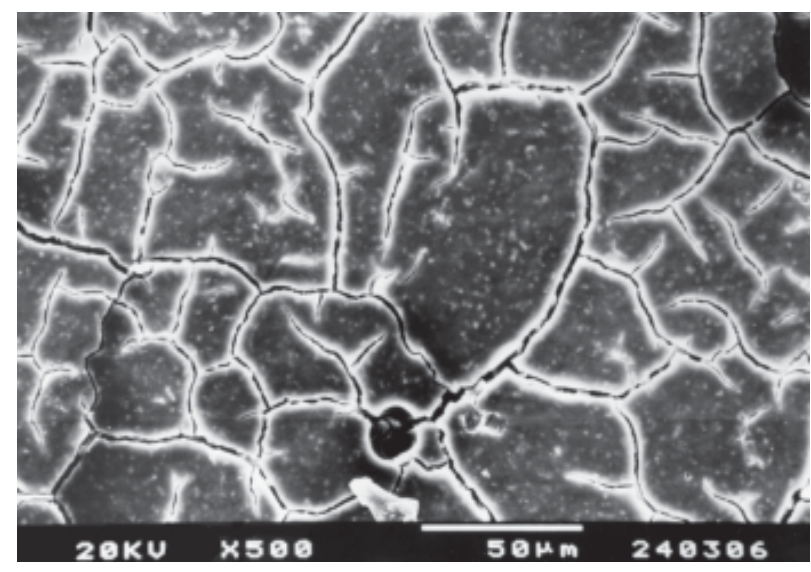

Figure 2. Morphological appearance of a glass ionomer specimen observed under scanning electron microscopy. Note the presence of voids and cracks. 
moisture, low mechanical strength and low wear resistance make glass ionomer restorations usually less durable (13).

Surface roughness of restorative materials has several clinical implications and alterations on surface topography and roughness are often used to determine the wear of a material. Increased roughness might be a predisposing factor to microbial colonization, which could potentially increase the risk of oral diseases. In addition, increase in surface roughness might indicate material deterioration $(10,11,14)$.

As ART implies in placement of a restoration that should remain in function in the oral cavity for a long period, it is important to evaluate the initial roughness of GICs usually indicated for this technique. The most commonly used parameter for characterizing surface roughness is the centre-line average roughness $(R a)$, which is the arithmetic mean deviation of the surface height from the mean line through the profile (9). Roughness can be related to a combination of factors that include the characteristics of the matrix, ratio and size of glass inorganic particles, exposition of these inorganic particles and formation of air bubbles during material preparation $(10-12,15)$.

Glass ionomer cements are usually hydrolytically unstable at initial stages of setting when exposed to air. If exposed to moisture, GICs can uptake water while essential ions can be lost. Worsening of the mechanical properties can be a consequence of both processes: water loss and/or uptake in early stages of the setting reaction (16). Therefore, glass ionomer stabilization was chosen as the first parameter for material evaluation.

Bollen et al. (17) considered the critical surface roughness $(R a)$ means for bacterial colonization of several dental materials to be $0.2 \mu \mathrm{m}$. In this study, except for Vitromolar, all GICs presented surface roughness means below this value. Surface roughness means higher than $0.2 \mu \mathrm{m}$ are likely to increase significantly bacterial adhesion, dental plaque maturation and acidity, which act on materials surface, thus increasing caries risk. However, GICs present anticariogenic action due to fluoride release $(12,14,18)$.

An increase in surface roughness can also be responsible for alterations in light reflection that can turn material surface opaque. It has been shown that a surface is considered reflective when imperfections are well below $1 \mu \mathrm{m}$ (19).
The SEM photomicrographs obtained in this study showed that, regardless of the commercial brand, all conventional GICs presented voids and cracks on their surface. Despite the differences on roughness means, SEM examination revealed a similar morphological surface pattern to each other. The cracks could have been produced during specimen processing for SEM analysis while the voids were probably included during mixing of GIC powder and liquid.

From a clinical standpoint, rougher surfaces predispose restored teeth to plaque accumulation, recurrent decay, gingivitis and loss of periodontal attachment. Moreover, restorations become unaesthetic because of staining and color changes resulting from loss of reflectivity (19).

In conclusion, the findings of this study showed that, from the tested conventional chemically cured glass ionomer cements, Fuji IX, Ketac Molar and Vidrion R presented acceptable surface roughness after setting reaction and without undergoing any stress while Vitromolar showed remarkably higher surface roughness.

\section{RESUMO}

O objetivo deste estudo foi avaliar a rugosidade superficial de quatro cimentos de ionômero de vidro convencionais quimicamente ativados (Fuji IX, Ketac Molar, Vidrion R e Vitromolar) comumente utilizados no tratamento restaurador atraumático (TRA), imediatamente após a manipulação do material. Vinte espécimes de cada material foram preparados e, após sua estabilização, foi realizada a leitura de sua rugosidade superficial. Os espécimes foram posteriormente examinados em microscopia eletrônica de varredura. Os dados foram submetidos à análise estatística por meio dos testes de Kruskal-Wallis e Mann-Whitney com nível de significância de 5\%. A comparação dos materiais aos pares mostrou diferença estatisticamente significante entre todos os materiais $(p<0.05)$, exceto entre o Ketac Molar e o Vidrion $\mathrm{R}$ que apresentaram resultados estatisticamente semelhante entre si $(\mathrm{p}>0.05)$. Com relação à rugosidade superficial, os materiais podem ser classificados em ordem crescente de rugosidade da seguinte maneira: Ketac Molar $<$ Vidrion $\mathrm{R}<$ Fuji IX $<$ Vitromolar. Conclui-se que, dentre os cimentos de ionômero de vidro avaliados, Fuji IX, Ketac Molar e Vidrion R apresentaram rugosidade superficial aceitável, enquanto o Vitromolar apresentou rugosidade superficial consideravelmente maior que os demais materiais.

\section{REFERENCES}

1. Wilson AD, Kent BE. A new translucent cement for dentistry. The glass ionomer cement. Br Dent J 1972;132:133135 . 
2. Pereira LCG, Nunes MCP, Dibb RGP, Powers JM, Roulet J, Navarro MFL. Mechanical properties and bond strength of glass ionomer cements. J Adhes Dent 2002;4:73-80.

3. American Academy of Pediatric Dentistry. Policy on alternative restorative treatment (ART). Pediatr Dent 2003;24:20.

4. Frencken JE, Pilot T, Songpaisan Y, Phantumvanit P. Atraumatic Restorative Treatment (ART): rationale, technique and development J Public Health Dent 1996;56:135140 .

5. Smales RJ, YIP H. The atraumatic restorative treatment (ART) approach for primary teeth: review of literature. Pediatr Dent 2000;44:294-298.

6. Frencken JE, Holmgren CJ. How effective is ART in the management of dental caries? Community Dent Oral Epidemiol 1996;27:423-430.

7. Smales RJ, Gao W. In vitro caries inhibition at the enamel margins of glass ionomer restoratives developed for the ART approach. J Dent 2000;28:249-256.

8. Yip HK, Peng D, Smales RJ. Effects of APF gel on the physical structure of compomers and glass ionomer cements. Oper Dent 2001;26:231-238.

9. Sidhu SK, Sheriff M, Watson TF. In vivo changes in roughness of resin-modified glass ionomer materials. Dent Mater 1997;13:208-213.

10. Yip HK, Lam WTC, Smales RJ. Fluoride release, weight loss and erosive of modern aesthetic restoratives. Br Dent $\mathrm{J}$ 1999; 197:265-270.

11. Yip HK, Lam WTC, Smales RJ. Surface roughness and weight loss of esthetic restorative materials related to fluoride release and uptake. J Clin Pediatr Dent 1999;23:321-326.

12. Rios D, Honório HM, Araújo PA, Machado MAA. Wear and superficial roughness of glass ionomer cements used as sealants, after simulated toothbrushing. Braz Oral Res 2002;16:343-348.

13. Hse KMY, Leung SK, Wei SHY. Resin-ionomer restorative materials for children: a review. Aust Dent J 1999;44:1-11.

14. Yip HK, Peng D, Smales RJ. Effects of APF gel on the physical structure of compomers and glass ionomer cements. Oper Dent 2001;26:231-238.

15. Geiger S, Ravchanukayev M, Liberman R. Surface roughness evaluation of resin modified glass ionomers polished utilizing poly (acrylic acid) gel. J Oral Rehabil 1999;26:704-709.

16. Yap AUJ, Teoh SH, Hastings GW, Lu CS. Comparative wear ranking of dental restorative materials utilizing different wear simulation modes. J Oral Rehabil 2001;24:574-580.

17. Bollen CML, Lambrechts P, Quirynen M. Comparison of surface roughness of oral hard materials to the threshold surface roughness for bacterial plaque retention: a review of the literature. Dent Mater 1997;13:258-259.

18. Weidlich P, Miranda LA, Maltz M, Samuel SMW. Fluoride release and uptake from glass ionomer cements and composite resins. Braz Dent J 2000;11:89-96.

19. Warren DP, Colescott TD, Henson HA, Powers JM. Effects of four prophylaxis pastes on surface roughness of a composite, a hybrid ionomer and a compomer restorative material. J Esthet Rest Dent 2002;14:245-251.

Accepted April 5, 2006 